\title{
Rhizobacteria antagonistic to the fungus Sclerotium cepivorum (Berk.t) in onion plants (Allium cepa L.)
}

\section{Rizobacterias antagónicas al hongo Sclerotium cepivorum (Berk.t) en plantas de cebolla (Allium cepa $\mathbf{L}$.)}

OCEGUEDA-REYES, Martha Delia, CASAS-SOLÍS, Josefina, GONZÁLEZ-EGUIARTE, Diego R. and VIRGEN-CALLEROS, Gil

Centro Universitario de Ciencias Biológicas y Agropecuarias, Universidad de Guadalajara. Zapopan. Jalisco, Camino Ramón Padilla Sánchez \#2100 Nextipac, Zapopan, Jalisco, México.C. P: 45200

ID $1^{\text {st }}$ Author: Martha Delia Ocegueda Reyes

ID $1^{\text {st }}$ Coauthor: Josefina, Casas-Solís / ORC ID: 0000-0001-7880-7240, Researcher ID Thomson: U-1318-2018, CVU CONACYT ID: 218087

ID $2^{\text {nd }}$ Coauthor: Diego R., González-Eguiarte / ORC ID: 0000-0001-6609-0780, CVU CONACYT ID: 3475

ID $3^{\text {rd }}$ Coauthor: Gil, Virgen-Calleros / ORC ID: 0000-0003-4172-8885, CVU CONACYT ID: 74671

DOI: 10.35429/JESN.2019.16.5.5.16

Received June 26, 2019; Accepted December 30, 2019

\begin{abstract}
Rhizobacteria are microorganisms attached to the roots of plants that colonize the rhizosphere, there is a great diversity with beneficial effects on crop development and they used in biological control. In this study, the antagonistic effect of rhizobacteria as biocontrollers of Sclerotium cepivorum Berk fungus, which cause white onion rot in large economic losses, was determined. Soil samples collected from onion plants on the farm located in Santa Anita, municipality of Tlaquepaque, Jalisco; for isolation of rhizobacteria and S. cepivorum from infected white rot bulbs. Rhizobacteria that showed antagonism against the fungus, were selected 14 treatments formed with onion plants in conditions of humidity, temperature and photoperiod constant in growth chamber for 36 weeks. Growth promotion variables were evaluated and the data analyzed by ANOVA. Rhizobacteria showed an antagonistic effect against the fungus and stimulated fresh weight, root length, stem and bulb in onion plants. Therefore, this PGPR is an alternative as a biofertilizer potential, thus avoiding degradation and contamination of the soil and yield of product quality and profitability for the producer.
\end{abstract}

Rhizobacteria, White rot, Sclerotium cepivorum

\begin{abstract}
Resumen
Las rizobacterias son microorganismos adheridos a las raíces de plantas que colonizan la rizosfera, existe una gran diversidad con efectos benéficos sobre el desarrollo de cultivos y se utilizan en el control biológico. En este estudio se determinó el efecto antagónico de las rizobacterias como biocontroladoras del hongo Sclerotium cepivorum Berk, que causan la pudrición blanca en cebolla con grandes pérdidas económicas. Se colectaron muestras del suelo de plantas de cebollas del predio ubicado en Santa Anita, municipio de Tlaquepaque, Jalisco; para aislamiento de rizobacterias y $S$. cepivorum a partir de bulbos infectados de pudrición blanca. $\mathrm{Se}$ seleccionaron las rizobacterias que mostraron antagonismo contra el hongo. Se formaron 14 tratamientos con plantas de cebolla en condiciones de humedad, temperatura $\mathrm{y}$ fotoperiodo constante en cámara de crecimiento durante 36 semanas. Se evaluaron variables de promoción de crecimiento y los datos se analizaron por ANDEVA. Las rizobacterias mostraron efecto antagónico contra el hongo y estimularon el peso fresco, longitud de raíz, tallo y bulbo en plantas de cebolla. Por lo tanto, esta PGPR es una alternativa como potencial biofertilizante, evitando así la degradación y contaminación del suelo y rendimiento de la calidad del producto y rentabilidad para el productor.
\end{abstract}

Rizobacterias, Pudrición blanca, Sclerotium cepivorum

Citation: OCEGUEDA-REYES, Martha Delia, CASAS-SOLÍS, Josefina, GONZÁLEZ-EGUIARTE, Diego R. and VIRGEN-CALLEROS, Gil. Rhizobacteria antagonistic to the fungus Sclerotium cepivorum (Berk.t) in onion plants (Allium cepa L.). Journal of Environmental Sciences and Natural Resources. 2019, 5-16: 5-16

\footnotetext{
* Correspondence to Author (email: jcasasmicro@gmail.com)

$\dagger$ Researcher contributing first author.
} 


\section{Introduction}

There is a great diversity of rhizobacteria attached to the roots of plants that has effects on the development of plants; In addition, they are used in biological control is an alternative to reduce the use of chemicals, such as agents that stimulate plant growth, soil and plant health; This favors the yield in the crops, however, the presence of diseases caused by pathogens are present in different crops, such as onions. This vegetable is widely cultivated and of great economic importance worldwide. In Mexico; in the report of advances of sowing and harvest of the national summary of the agricultural year 2018, it refers to a tenth first place in production in the last cycle. With 20,919 hectares sown, only a total of 5,560 hectares were harvested (SIAP-SAGARPA, 2019).

In Mexico, the onion is vulnerable to fungal pathogens that cause the disease called white rot caused by Sclerotium cepivorum Berk, causing large economic losses and a decrease in product quality; affects both foliage and bulb (Delgado Ortiz et al., 2018); It is easily disseminated through sclerotia and has a very high viability in adverse conditions and can remain for long periods in the soil.

However, to combat this infection, agrochemicals are used, so it is necessary to look for biocontrol alternatives, to avoid soil contamination and decrease in product quality. This disease causes great economic losses; Affected farmers opt for alternatives such as changing crops, a strategy that is not safe because the fungus is activated with exudates released by the onion plant; causing serious damage and also to other species of this same genus (Granados and Wang, 2005). An alternative for biological control with antagonistic microorganisms such as PGPR's, which suppress diseases caused by phytopathogens through the production of siderophores, synthesis of antibiotics, enzymes or fungal compounds or both (Serret-López et al., 2016).

The present work proposed isolating PGPR rhizobacteria biocontrollers, as an alternative for the management of S. cepivorum fungus in onion plant (Allium cepa L.) and have a more profitable product for the producer.

\section{Background}

The term rhizosphere was introduced by Lorenz Hiltner (1904), to refer to the area where the microbial populations of bacteria that develop fundamental activities around the root inhabit and activate (Arshad and Frankenberger, 1998; Saharan and Nehra, 2011). In 1978 Kloepper called them Plant Growth Promoting Rhizobacteria Rhizobacteria (PGPR), for its acronym in English.

These beneficial soil bacteria play an important role in increasing plant growth and increasing their defense against other diseasecausing microorganisms. PGPRs are classified according to their mechanisms of action; some act in the development of the plant since they increase the availability of nutrients in the rhizosphere, inducing plant development regulated by the action of phytohormones such as; auxins, 3-indole-acetic acid, gibberellins, cytokinins, abscisic acid, activity of the enzyme 1-aminocyclopropane-1-carboxylic acid deaminase (ACC deaminase), which regulates ethylene levels, converting ACC into $\alpha$ ketobutyrate and ammonium (Glick, 2014; Esquivel-Cote et al., 2013), nutritional elements such as iron, phosphorus and aluminum (Carcaño et al., 2006), in addition, increase the amount of roots and thus the water absorption capacity and nutrients.

Other mechanisms act to reduce the harmful effect of phytopathogens through the production of antagonistic substances (tetrasulfides, thiols, thiophenes and sulfur dioxide) and as producers of siderophores that sequester the iron present in the medium (Corrales-García and Ciro, 2010; Glick, 2014), as has been demonstrated, in the different mechanisms of action of a bacterial biological compound that limits the development of pathogens as indicated by the Fungicide Resistance Committee (FRAC, 2018). However, the selection of microorganisms is based on the capacity for increased production of metabolites of interest or antagonistic factor, on the use of organic substances as a source of nutrients and on the energy that allows them to survive and efficiently prevent the proliferation of phytopathogens, acting through the synthesis of antibiotics, or enzymatic biocontrol processes (Desai et al., 2012), important for agriculture especially in vegetable crops. 


\section{Onion crop}

The onion (Allium cepa L.) is one of the most cultivated vegetables worldwide. This crop belongs to the Liliaceae family, there are 600 species and it belongs to the Allium genus, composed of: onion (A. cepa L.), garlic (A. sativum L.), leek (A. porrum L.) and chives (A. schoenoprasum L.). Its root system consists of 20 to 200 roots that can develop from 35 to 60 $\mathrm{cm}$ from the soil, stimulate a low absorption of nutrients and water. It has a true stem, cylindrical and hollow leaves, which together form the false stem at the top and bottom, the bulb develops when the conditions are optimal for photoperiod and temperature, the color of the onion is associated with the variety and presents white flowers.

The quality of the onion is of great economic importance, a successful production depends on the management and control of pests influenced by climatic factors. In addition to the integral application and essential elements for the onion plant is magnesium, manganese, zinc, boron and sulfur by foliar route and nitrogen that provides firmness of the bulb, color, thickness of the scales and neck that are quality factors, to achieve maximum performance; the absence of macronutrients and micronutrients limits the nutritional balance of this vegetable, because they regulate the expression of the productive potential of the crop and the quality of the product as is the case of the bulb (Gómez, 2007).

The growth is fast and develops in different types of soils and climates. However, it tolerates temperatures below zero, it adapts to regions that range between 10 and $20^{\circ} \mathrm{C}$; sunlight favors bulbification (Gómez, 2002; SIAP-SAGARPA, 2014). This plant is typical of transplanting, it is done when the plants are 40 to 60 days (approximately $15 \mathrm{~cm}$ high) after planting (Granados and Wang, 2008). In the world more than 1,100 million tons of onion are produced, in an area of 4.2 million hectares (FAO). In Mexico, onion is grown in almost the entire country, it is the third most cultivated vegetable. $95 \%$ of the production is carried out through irrigation and in two cycles: Autumnwinter and spring-summer, the first being the one with the highest production (SAGARPA, 2014). Due to its culinary properties and health benefits, it has a high demand, so it represents a source of employment.
Due to the problem that exists in this country, of large losses in onion crops, affected by the disease such as white rot caused by the fungus Sclerotium cepivorum Berk., It is necessary to determine and evaluate the antagonistic effect of rhizobacteria as biocontrollers of this mushroom.

\section{Onion disease}

Onion crops are affected by white rot disease, caused by the fungus Sclerotium cepivorum (Berk.) Is one of the most important (Sarmiento and Velandía, 2013; Castillo et al., 2016) ;; because it affects the genus Allium (onion, garlic, leek); the onion is affected at any stage of development, the infection increases as the radical system grows, the bulb and can cause losses up to $100 \%$ of the crops. In Mexico, it was first presented in Zacatecas in 1990 (Colina, 2017; Reveles-Hernández et al., 2014). The most affected states are: Aguascalientes, Chihuahua, Guanajuato, Jalisco, Morelos, Michoacán, Puebla, Querétaro, Tlaxcala and Zacatecas (Velásquez-Valle and Reveles Hernández, 2016).

S. cepivorum belongs to the Mycelial Stenrilia Order and the Sclerotiniaceae Family (Sarmiento and Velandía 2013; Castillo et al., 2016). The sclerotia are stimulated by sulfur compounds present in the radical exudates of the onion plant such as: aquil cysteine and sulfoxides, easily disseminated and that once established in the soil can remain for several decades (Ortega et al., 2011; Reveles Hernández et al., 2014; Hussain et al., 2017; Elshahawy et al., 2017), these produce volatile compounds of allyl and n-propyl sulfide (ColeySmith et al., 1990), the mycelium contains material of reserve, which allows them to remain at rest when the environmental conditions are adverse (Vera et al., 2005; Ortega et al., 2011), due to the viability of up to $90 \%$ and being able to remain inactive for up to 40 years (Reveles-Hernández et al., 2014), these are activated when the environmental conditions are favorable, in the presence of sulfur compounds produced by the onion tuber (Coley-Smith et al., 1990). And the environmental conditions that favor the development of the fungus is the temperature in the soil $\left(18\right.$ to $\left.22^{\circ} \mathrm{C}\right)$ and the optimum $\mathrm{pH}$ is 2 to 7 (Crowe et al., 1980). 
Chemical agents mainly mancozeb, captan and hydrogen peroxide have been used with positive effect for the control of white rot (Velásquez-Valle and Reveles Hernández, 2016); and tebuconazole alone or in combination with calcium nitrate, reduced the severity of damage from 56 to $92 \%$ (Siyoum et al., 2013; Hussain et al., 2017); However, the inappropriate use of pesticides has had a great impact on the environment, has phytotoxicity and accumulation of residues and immersion in the roots of edible plants (Ulacio et al., 2010; Van Dyk and Pletschke, 2011; Reveles Hernández et al., 2014). Currently, native fungi and bacteria that inhabit the soil have been used for their control, this depends on the capacity and environmental conditions and soil type (Mahdizadehnaraghi et al., 2015; Vega-Celedón et al., 2016; Kumbhar et al., 2018). Rhizobacteria have a potential for biocontrol, which reduce the density of the inoculum avoiding the formation of sclerotia (Esquivel et al., 2013) and endomiccorrhizal fungi (Glomus intraradices), capable of providing a protective effect similar to the fungicide Folicur (Jaime et al. , 2008).

\section{Methodology}

\section{Rhizobacteria and fungus isolation Sclerotium cepivorum}

Soil samples were collected from onion plants on the farm located in Santa Anita, municipality of Tlaquepaque, Jalisco, Mexico, with geographical coordinates: the $20^{\circ} 55^{\prime} \mathrm{N}$ and $103^{\circ} .44^{\prime} \mathrm{W}$. For the isolation of rhizobacteria plants were selected of onion with greater stem and bulb development: $10 \mathrm{~g}$ of soil adhered to the roots were taken, diluted in $90 \mathrm{~mL}$ of distilled water, homogenized and subsequently serial dilutions $\left(10^{-7}\right)$ were made, one $\mathrm{mL}$ of The last three dilutions, which were inoculated on plates with nutrient agar (AN), were incubated at $37{ }^{\circ} \mathrm{C}$ for $24 \mathrm{~h}$. The colonies were selected and purified; they were kept in test tubes to evaluate the antagonistic effect.

The isolation of Sclerotium cepivorum, the methodology described by Vimard et al. (1986), which consisted of separating sclerotia from affected onions with white rot, were disinfected with sodium hypochlorite $(0.5 \%)$ for $3 \mathrm{~min}$ and subsequently washed in distilled water, fragmented for inoculation in Sabouraud Dextrose Agar medium (ADS).
Were incubated at $20^{\circ} \mathrm{C}$ and mycelium development was observed until sclerotia formation (Ortega-Aguilar et al., 2011).

\section{Rhizobacterial antagonism on S. cepivorum}

Previously, the S. cepivorum fungus was grown in $\mathrm{ADS}$ and a $5 \mathrm{~mm}$ diameter mycelium disc was removed and placed in plates of the same medium and incubated at $20^{\circ} \mathrm{C}$; on the third day, the plates with different cultures of rhizobacteria were inoculated by a single groove $25 \mathrm{~mm}$ away around the mycelial disk and incubated at $20^{\circ} \mathrm{C}$. Inoculation of the fungus was only used as a control and it was concluded when the development covered the total of the box (Sarti and Miyazaki, 2013). The test was performed in duplicate. Halo diameters of inhibition were measured for each rhizobacterium and those with the greatest antifungal effect were selected to assess antagonism and growth promotion in vivo.

\section{Antagonism and growth promotion by rhizobacteria in onion plants in growth chamber conditions}

Selected rhizobacteria were inoculated in nutrient broth, adjusted to the McFarland scale at 0.5 (10.8 CFU mL-1). Onion plants with a growth of three weeks were used with a bulb 3 $\mathrm{cm}$ wide and long. By means of a cut, the size of leaves at $14 \mathrm{~cm}$ high and $4 \mathrm{~cm}$ long at the root was homogenized from the bulb. The bulb was made an incision of approximately $2 \mathrm{~cm}$ to favor the treatments, 14 treatments were formed with the rhizobacteria and fungus (Table 1).

The rhizobacterial treatments were immersed in a bacterial solution $(15 \times 107 \mathrm{CFU}$ $\mathrm{mL}-1)$ according to the treatment, for 15 minutes. To the treatments that were added fungus, 5 multidisc myceliums containing about 25 to 30 sclerotia were incorporated and on the other hand, a control without rhizobacteria or fungus, subsequently transplanted into unicel containers containing $400 \mathrm{~g}$ of previously sterilized soil ( $\left.121^{\circ} \mathrm{C} / 15 \mathrm{~min}\right)$. 


\begin{tabular}{|l|l|l|}
\hline Witness & 6. RB1+H & $11 . \mathrm{RB} 2+\mathrm{RB} 3$ \\
\cline { 2 - 3 } Fungus & $7 . \mathrm{RB} 2+\mathrm{H}$ & $12 . \mathrm{RB} 1+\mathrm{RB} 2+\mathrm{H}$ \\
RB 1 & $8 . \mathrm{RB} 3+\mathrm{H}$ & $13 . \mathrm{RB} 1+\mathrm{RB} 3+\mathrm{H}$ \\
RB 2 & $9 . \mathrm{RB} 1+\mathrm{RB} 2$ & $14 . \mathrm{RB} 2+\mathrm{RB} 3+\mathrm{H}$ \\
RB 3 & $10 . \mathrm{RB} 1+\mathrm{RB} 3$ & \\
\hline
\end{tabular}

$\mathrm{RB}=$ Rhizobacteria $\mathrm{H}=$ Fungus

Table 1 Treatments used in onion plants Treatments

The plants were kept in a growth chamber of the Biotechnology Laboratory of the Department of Botany of the CUCBA for a period of 36 days; under the following conditions: relative humidity $30 \%$, constant temperature of $20{ }^{\circ} \mathrm{C}$ and light / dark photoperiods (12/12).

At the end of the time, the following variables in the plants were evaluated: fresh and dry weight, root length, stem and bulb; the number of leaves was measured to evaluate the growth promotion and the effect of $\mathrm{S}$. cepivorum on onion plants.

\section{Experimental design and statistical analysis}

The results obtained were performed with a completely randomized experimental design; The Sigma Plott 11.0 program was used for statistical analysis. A one-way analysis of variance (ANDEVA) was applied, for the comparison between the groups and the Kruskal-Wallis test in pairs, to determine the significant difference between the groups at $\mathrm{P}$ $<0.05$.

\section{Results and Discussion}

\section{Isolation of rhizobacteria and fungus $S$. cepivorum}

656 rhizobacteria from the rhizosphere of onion plants were isolated; This is related to the great bacterial diversity of free life that adapt and colonize the soil (Saleem et al., 2007; Luna et al., 2013).

On the other hand, the S. cepivorum fungus was isolated and morphological characteristics were observed showing abundant whitish mycelium, formation of black, round sclerotia, which had a diameter of $54 \mathrm{~nm}$ on average per sclerotia (Figure 1A and 1B ); the results coincide with what is described in the taxonomic keys of Imperfect Fungi (Sarmiento and Velandía, 2013).

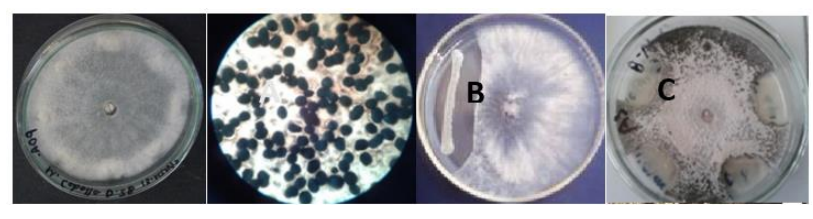

Figure 1 Development of mycelium (A) and sclerotia (B) of Sclerotium cepivorum and antagonism of the genus Bacillus (C and D)

\section{Rhizobacterial antagonism on S. cepivorum}

Of the 656 bacterial isolates, only 20 isolates showed antagonism with inhibition halos less than $18 \mathrm{~mm}$ and three isolates with 20 to 23 $\mathrm{mm}$ on the fungus under study (Figure $1 \mathrm{C}$ and 1D); these last three isolates were selected and designated as RB1, RB2 and RB3; were identified by the VITEX 2 system with the BCL reactive card (bioMérieuxMR) for positive Gram spore-forming bacilli, with a $95 \%$ reliability; they showed morphological characteristics, such as large cream-colored colonies, smooth surface, viscous consistency, opaque density, wavy margin and dyeing as gram-positive bacilli with endospore formation. The three selected isolates belong to the genus Bacillus; the rhizobacteria RB1 and RB3 as Bacillus subtilis and RB2 as Bacillus amynololiquefaciens, these characteristics are characteristic of this genus (Tejera-Hernández et al., 2011; Oslizlo et al., 2015).

This antagonistic effect on S. cepivorum may be due to the fact that the rhizobacteria isolated in this work can be producers of antimicrobial molecules such as lipopeptides (Sarti and Miyazaki, 2013; Villarreal-Delgado et al., 2017). The Resistant Fungicide Action Committee (FRAC) listed them to the rhizobacteria Bacillus subtilis and B. amyloliquefaciens, as producers of fungal substances classified in group F (F6); that act in the transport or synthesis of lipids that affect the function and integrity of the cell membrane of pathogens (FRAC, 2018).

Other studies have shown that B. subtilis acts in the control of fungi of the genus Fusarium (Yesid et al., 2012; Mejía-Bautista et al., 2016; Da Silva et al., 2018). This Bacillus is an effective soil and rhizosphere colonizer with great genetic diversity (Montor-Antonio et al., 2014); which favors the antagonistic activity against pathogens and consequently induces the developinent of the plant. 
In addition, Sánchez et al., (2016), record the production of Iturin A by these bacteria, such as fengicins that cause an osmotic imbalance in the spores and antifungal activity against the filaments of the fungus; Surfactin inhibits spore germination (ArjonaLópez, 2019) and the excretion of antimicrobial enzymes such as $\beta$-glucosidases and proteases that control leaf and root diseases (Da Silva et al., 2018). In studies with Pseudomonas fluorescens and B. subtilis they presented inhibition against fungi such as Rhizoctonia solani, Fusarium oxysporum, and Sclerotium sosfsii (Paredes Escalente et. Al., 2009) and Bacillus spp. against Macrophomina phaseolia (Reyes et al., 2011), among others.

The three rhizobacteria were subjected to 24 and $37^{\circ} \mathrm{C}$ to determine if the conditions of humidity and temperatures do not affect the vital processes of the genus Bacillus, as well as the effects of microbial antagonism against S. cepivorum. The results showed that it does not affect bacterial viability when grown at these temperatures (37 and $24^{\circ} \mathrm{C}$ ) and humidity of 50, 75 and $100 \%$; Some authors mention that there is a great diversity of bacteria capable of surviving in diverse environments (Estrada Bonilla et al., 2009; Calvo and Zúñiga, 2010; Gómez et al., 2017) and this favors the adaptation process and the ability to antagonize microbial (Gouda et al., 2018; Soto et al., 2018).

Rhizobacteria in the promotion of growth and control of $S$. cepivorum fungus on onion plants

The results of the variables studied in the 14 treatments in the growth chamber (Figure 2), of the onion plants, only showed a significant difference $(P \leq 0.05)$ in the variables: length, fresh and dry root weight.

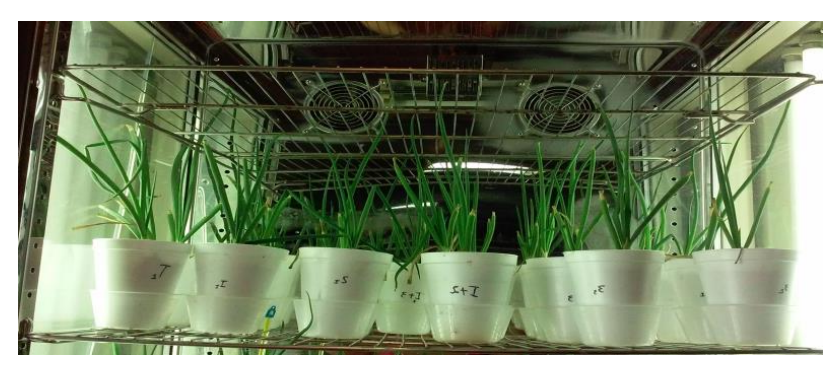

Figure 2 Onion plants in growth chamber
The root length results (Figure 3) show a better development with the use of rhizobacteria individually (treatments 3 to 5), which induce root development, compared to the control; similarly the same behavior was observed in fresh weight where rhizobacteria individually, as well as treatment 1 (plant without fungus, or bacteria) and when an infection occurs with $S$. cepivorum rhizobacteria try to compensate with fresh weight and root length and this is closely related to dry weight. On the other hand, the use in consortium form inhibits these variables compared to the development of the fungus seedling. Therefore, the best treatments were those that were added separately each of the rhizobacteria.
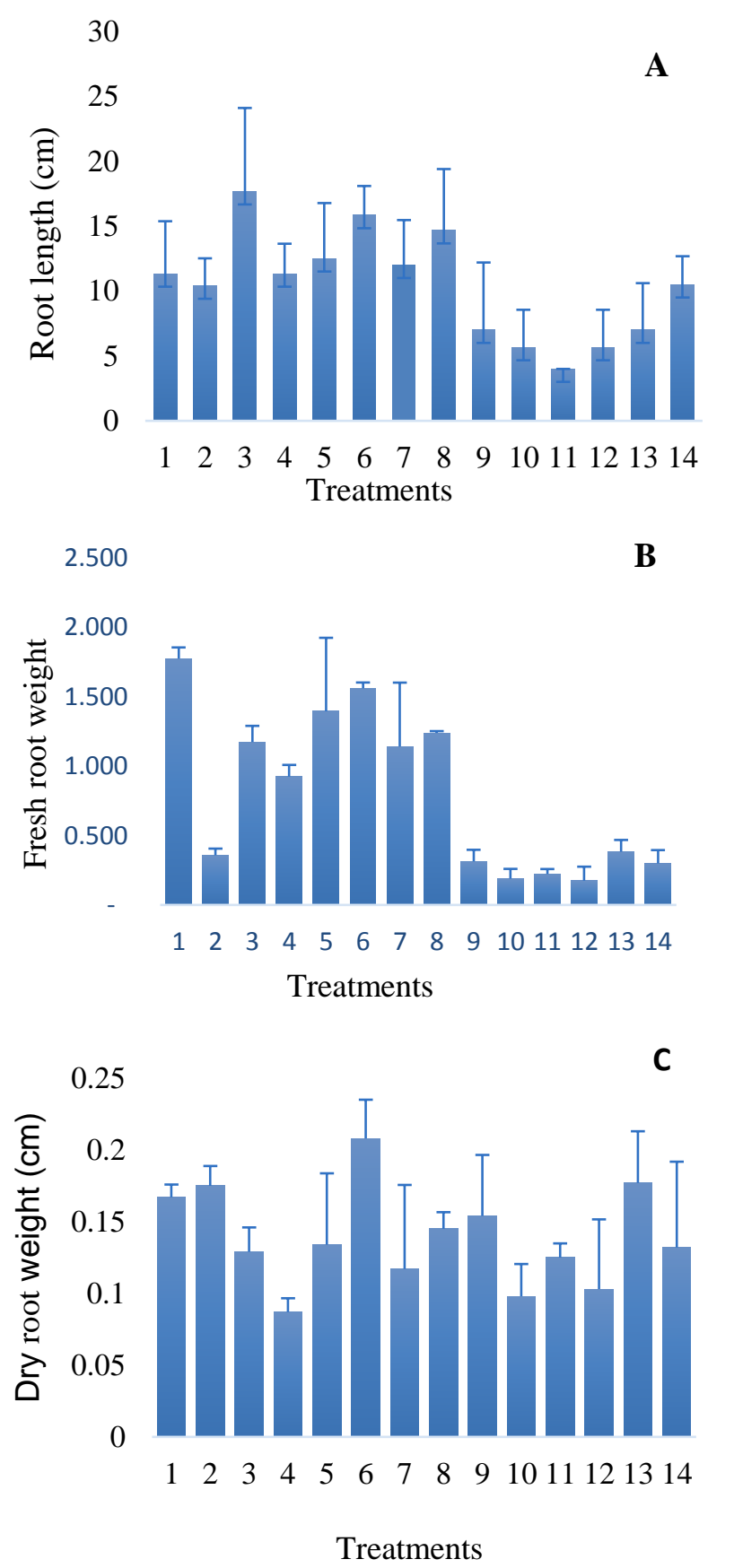

Figure 3 Treatments applied in onion plants (growth chamber)

OCEGUEDA-REYES, Martha Delia, CASAS-SOLÍS, Josefina, GONZÁLEZ-EGUIARTE, Diego R. and VIRGEN-CALLEROS, Gil. Rhizobacteria antagonistic to the fungus Sclerotium cepivorum (Berk.t) in onion plants (Allium cepa L.). Journal of Environmental Sciences and Natural Resources. 2019 
In the case of stem length there was no significant difference, however treatments with bacteria behaved in an equivalent manner both individually and in consortium in the development of the stem, although when the bacteria is individually and the plant is infected by fungus it is more vulnerable, but manages to survive and develop the stem despite the size of the root (Figure 4 and 5). With respect to the bulb length there was no significant difference, in this variable a similar behavior was shown with and without the presence of the fungus; perhaps this result is due to the incision that was made to the bulb and by submerging it and impregnated with the bacterial solution it protects it against the S. cepivorum fungus. Ortiz et al., (2016) point out that immersion in bacterial solution of PGPR, benefits the development and health of the plant.

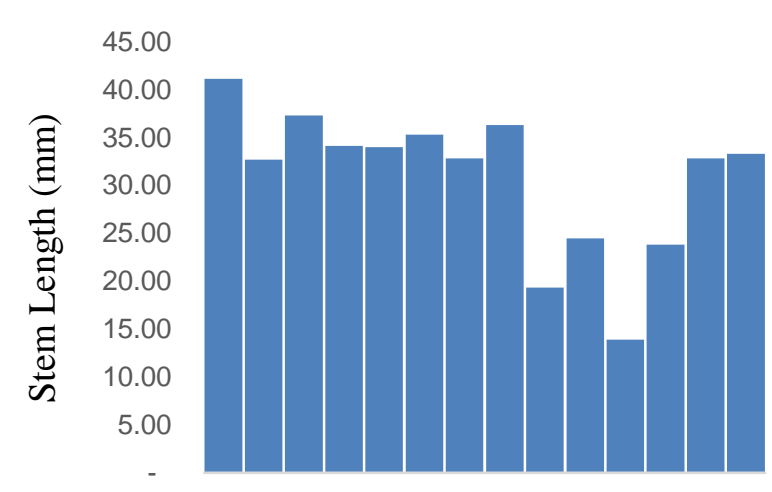

$\begin{array}{llllllllllllll}1 & 2 & 3 & 4 & 5 & 6 & 7 & 8 & 9 & 10 & 11 & 12 & 13 & 14\end{array}$

\section{Treatments}

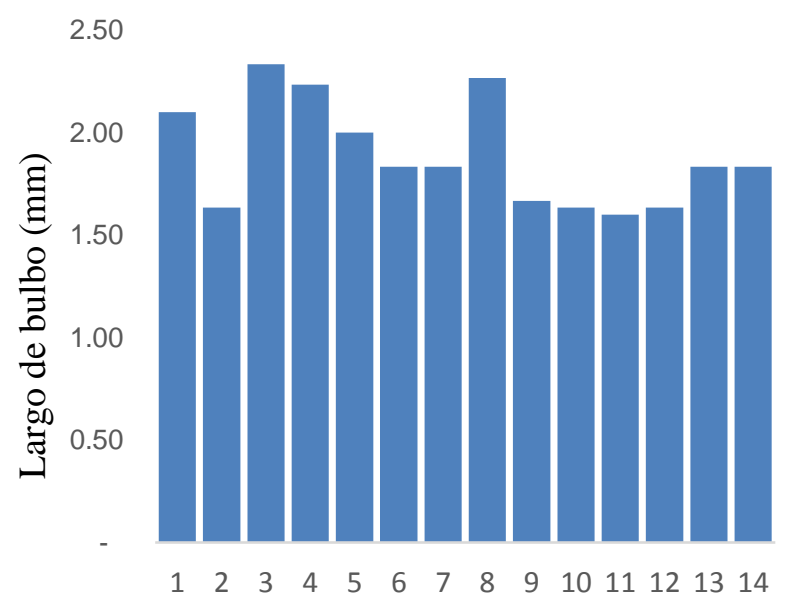

Treatments

Figure 4 Treatments applied in onion plants (growth chamber)

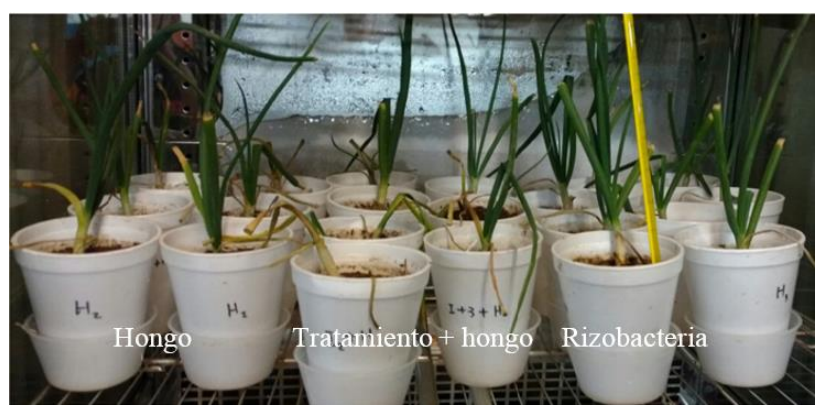

Figure 5 Treatment with Rhizobacteria and infection with S. cepivorum in onion plants

This effect may be due to the fact that the rhizobacterium acts at the root level which agrees with Gouda et al., (2018), which mention that the genus Bacillus improve the growth of plants because it produces phenazine, carboxylic acid, antifungal compounds 2hexium, 5 resorcinol propyl, pyrrolnitrin (Arjona-López, 2019), 2,3-butanadiol, acetoin, lipopeptides and glycopeptides such as ramnolipids and surfactins, which are effective in inhibiting the growth of pathogenic fungi, due to their antifungal activity and ability to solubilize the main components of microbial cell membranes and allow greater chance of survival in habitats with high competition for nutritional elements (Rios-Velasco, et al., 2016).

On the other hand, the development of microbial populations (Salazar-Henao et al., 2016), which allows the plant to improve the absorption of nutrients as mentioned by Ortiz et al., (2016). Bacillus amyloliquefaciens and subtilis can inhibit fungal pathogens by the production of lithic enzymes such as chitinases, degrade the cell wall of fungi and prevent the spread of hyphae (Moreno et al., 2018). Through these phyto-stimulants, it can also promote the protection and capacity of plants to resist long periods of drought (Rojas-Solís et al., 2013). These results agree with Hussini et al., (2019), who report that bacterial antagonists either individually or in consortium have the potential to develop as bioinoculants and for ecological management.

The soil is a complex system of beneficial effects due to interactions with rhizobacteria, which depend on both the strain and the plant; the genus Bacillus, has influence on variable of plants of the type of mini-tubers and tubers. 
Alvarado-Capo et al., (2015), who worked with potatoes, mention that Bacillus has the advantage of forming endospores which gives great stability to act as biofertilizers or biofungicides (Desai et al., 2012) and allow them to resist adverse environmental conditions, favoring the storage of products (Moreno et al., 2018). Rhizobacteria favor root length and fresh weight and dry weight in onion plants, which coincides with the results of Angulo-Castro et al., (2018), who worked on the application and inoculation of bacterial strains in plants, demonstrating that there was greater development in plant height, leaf area, stem diameter and radical volume, they demonstrated that rhizospheric and endophytic bacteria stimulate the emergence and growth of seedlings of this species.

Because the bacteria under study B. subtilis and B. amyloliquefaciens are producers of AIA, they activate ACC synthase, they favor the production of ACC, and therefore, of ethylene, which inhibits root growth in large quantities and in small amounts that favor the root, have an antagonistic effect against pathogens (Tariq, 2019).

Many rhizobacteria show some of the metabolic attributes that favor the growth and development of plants, among which the enzymatic activity of ACC deaminase, salinity tolerance, AIA production and presence of siderophores are highlighted, as was demonstrated in previous studies by these bacteruae and in the same way with Cell Free Extracts. Rhizobacteria have been shown to produce AIA from the presence of L-tryptophan (Lavenus and Cols, 2013); this in turn activates the enzyme ACC synthetase that favors the production of ACC and therefore regulates ethylene levels, which benefits the development of the root (Angulo et al., (2014). Therefore, the rhizobacteria of the genus Bacillus It is a natural alternative against diseases that affect onion crops, such as growth promoters because of the benefits they have to improve the health of these plants.

\section{Conclusions}

Rhizobacteria showed an antagonistic effect against the fungus and stimulated fresh weight, root length, stem and bulb in onion plants. These results reflected that the application of rhizobacteria individually induces better plant development compared to a consortium.
Therefore, this PGPR is an alternative as a biofertilizer potential, thus avoiding degradation and contamination of the soil and yielding product quality and profitability for the producer, which allows reducing the demand for agricultural inputs such as chemical fertilizers. However, it is important to produce healthy plants to achieve greater yield and if these rhizobacteria inhibit the growth of pathogenic fungi, they are the alternative for the management of the S. cepivorum fungus that affects the onion.

The inoculation of beneficial bacterial strains is recommended through the incision and submersion of the plant tuber, in order that the plant is induced to systemic resistance, which can be used taking advantage of the stage of transplanting onions plants.

\section{Contribution}

In Mexico, onion production has been affected by the fungal diseases that affect this vegetable, caused by the fungus S. cepivorum Berk., Causing large economic losses and a decrease in product quality, however, to combat this infection they are used agrochemicals that affect the environment and pollute the soil. With this work, this problem can be solved using the rhizobacteria Bacillus subtilis and B. amyloliqeifaciens as a biocontrol alternative for the management of the S. cepivorum fungus, as well as the development and increase of onion quality (Allium cepa L.) to be sustainable and profitable for the producer.

\section{References}

Al-Hussini, H. S., Al-Rawahi, A. Y., AlMarhoon, A. A., Al-Abri, S. A., Al-Mahmooli, I. H., Al-Sadi, A. M., \& Velazhahan, R. 2019. Biological control of damping-off of tomato caused by Pythium aphanidermatum by using native antagonistic rhizobacteria isolated from Omani soil. Journal of Plant Pathology. 101(2):315-322.

Arshad, M. y W.T. Frankenberger Jr. 1998. Plant growthregulating substances in the rhizosphere: Microbial production and functions. Advances in Agronomy. 62:45-151. 
Arjona-López, J. M., Tienda, S., ArjonaGirona, I., Cazorla, F. M., \& López-Herrera, C. J. 2019. Combination of low concentrations of fluazinam and antagonistic rhizobacteria to control avocado white root rot. Biological Control. 103996.

Angulo-Castro, A., Ferrera-Cerrato, R., Alarcón, A., Almaraz-Suárez, J.J., DelgadilloMartínez, J., Jiménez Fernández, M., GarciaBarradas, O. 2018. Crecimiento y eficiencia fotoquímica del fotosistema II en plántulas de 2 varidades de Capsicum annuиm L. Revista Argentina Microbiologica. 50(2):178-188.

Angulo, C. V., Sanfuentes, A. E., Rodríguez, F., Sossa, E.K., 2014. Caracterización de rizobacterias promotoras de crecimiento de plántulas de Eucalyptus nitens. Asociación Argentina de microbiología. 46(4):338-347.

Alvarado-Capo, Y., Leiva-Mora, M., CruzMartín M., Mena, E., Acosta-Suárez, M., Roque, B., Pichardo, T., García-Aguila, L., Jiménez-Terry, F., Hurtado, O., Veitia, N., Padrón, L. 2015. Efecto de Bacillus spp. Sobre el crecimiento y rendimiento agrícola de plantas in vitro de papa cv. "Romano" en casa de cultivo. Biotecnología Vegetal. 15(2):115-122.

Calvo, P. y Zúñiga, D. 2010. Caracterización fisiológica de cepas de Bacillus spp. aisladas de la rizosfera de papa (Solanum tuberosum). Ecología aplicada. 9(1):31-39.

Carcaño-Montiel, M. G., Ferrera-Cerrato, R., Pérez-Moreno, J., Molina-Galán, J. D., Bashan, Y. 2006. Actividad nitrogenasa, producción de fitohormonas, sideróforos y antibiosis en cepas de Azospirilum y Klebsiella aisladas de maíz y teocintle. Terra Latinoamericana. 24(4):493502.

Castillo, H., Rojas., Villalta, M., 2016. Actividad antagonista de Gliocladium sp. contra Sclerotium cepivorum. Tecnología en Marcha. 57-54.

Coley-Smith, J.R. 1990. White rot disease of Allium: problems of soil-borne diseases in microcosm. Plant Pathology. 39:214-222.
Colina, C. C. 2017. Evaluación de las propiedades iniinflamatorias, antiinflamatorias, antioxidantes e hipolipidémicas de cebolla procesada como ingrediente funcional in vitro y en un modelo animal.Tesis doctoral. Universidad Complutense. Madrid. España. 235p.

https://eprints.ucm.es/46542/1/T39618.pdf.

Corrales-García, L. L., y Ciro, G. L. 2010. Péptidos con actividad antimicrobiana producidos por microorganismos nativos. Revista de la Facultad de Química Farmacéutica. Universidad de Antioquia, Medellín, Colombia. 17(2):181-190.

Crowe, F.J., Hall, D.H. 1980. Soil temperature and moisture effects on sclerotium germination and infection of onion seedlings by Sclerotium cepivorum. Phytopathology.70:74-78.

Da Silva, S. R., Moutinho, L. Brenda., Dos Santos, R. D., Vasconcelos-Rodrigues, I. S., Talamini, V., Fernandes, F. M., Fernades, M. R.P. 2018. Using antagonistic soil bacteria anda their cell-free filtrates to control the black rot pathogen Xanthomonas campestri pv. campetris. Journa of Phytopathology. 166(7-8): 495-501.

Desai, S., Grover, M., Amalraj, E. L. D., Kumar, G. P., Ahmed, S.K.M. H. 2012. Exploiting Plant Growth Promoting Rhizomicroorganisms for Enhanced Crop Productivity. En: Satyanarayana T, Bhavdish Narain Johri, Anil Prakash (Eds.). Microorganisms in sustainable agriculture and biotechnology. 12:227-242.

Elshahawy, I.E., Saied, N. M., Abd-El-Kareem, F., Morse, A. A. 2017. Field application of Sclerotial micoparasites as biocontrol agents to Stromatinia cepivora, the cause of onion White rot. Journal of Plant Pathology. 99(2):391-401.

Esquivel-Cote, R., Gavilanes-Ruiz, M., CruzOrtega, R., Huante, P. 2013. Importancia agrobiotecnológica de la enzima ACC desaminasa en rizobacterias. Una revisión. Universidad Autónoma de México. Revista de Fitotecnia Mexicana. 36(3):251-258. 
Estrada-Bonilla, G. A., Bonilla Buitrago, R. R., Divan Baldani, V. L. 2009. Efecto de diferentes temperaturas de almacenamiento sobre la calidad de bioinoculantes turbosos. Corpoica. Ciencia y Tecnología Agropecuaria. 10(2):205213.

Farfán, L. M., Benítez, S. V., Hoyos-Carvajal, L. M. 2014. Sensibilidad de bacterias procedentes de pasifloras a antibióticos y productos cúpricos. Revista colombiana de Ciencias hortícolas. 8:1. 2033.

FRAC, Fungicide resistace action committee. 2018. Code List $\odot$. pp.1-14. http://www.phibase.org/images/frac. (consulta, en Agosto de 2019).

Glick, B. 2014. Bacteria with ACC deaminase can promote plant growth and help to feed the world. Special Issue on Plant Growth Promotion. 169(1):30-39. ISSN 1435-8107.

Glick, R. B. 2012. Plant growth promoting bacteria: Mechanisms and applications. Hindawi publishing corporation, Scientifica ID963401 15 http://dx.doi.org/10.6064/2012/963401.

Glickmann, E., Dessaux, Y. 1995. A critical examination of the specificity of the Salkowski reagent for synodic compounds produced by phytopathogenic bacteria. Applied and environmental Microbiology. 61(2):793-796.

Gómez, P. E., Ruiz, D. B., Farjardo, S., Eichler, L. B., Samson, R., Van, D. P., López, S. R., Fernández, P. M. 2017. Caracterización de rizobios aislados de nódulos de frijol Caupí en suelos salinos de Cuba. Cultivos tropicales. 38(4):3949.

Gómez, M.I., Castro, H.E., Gómez, C. J., Ferney, G. O. 2007. Optimización de la producción de la cebolla cabezona (Allium cepa) mediante el balance nutricional con magnesio y micronutrientes ( $\mathrm{B}, \mathrm{Zn}$ y $\mathrm{Mn}$ ), Valle Alto de Rio Chicamocha, Boyacá. Agronomía Colombiana. 25:2.339-348.

Gouda, S., R., Kerry., Das, G., Paramithiotis, S., Han-Seung, S., Patra, J. K. 2018. Revitalization of plant growth promoting rhizobacateria for sustainable development in agriculture. Microbiological research 206:131140.
Granados y Wang. 2005. Aislamiento e identificación de hongos asociados a esclerocios de Sclerotium cepivorum, causante de la pudrición blanca de la cebolla, en la zona alta de Cartago, Costa Rica. Agronomía Costarricense. 29(1):57-66.

Granados y Wang. 2008. Efecto de biocontroladores aislados en fincas productoras de cebolla sobre la pudrición blanca (Sclerotium cepivorm). Agronomía Costarricense. 32:1. 9-17.

Hussain, W., Elzaawely, A. A., El Sheery, N. I., Ismail, A. A., El-Zahaby, H. M. 2017. Biological control of onion white rot disease caused by Sclerotium cepivorum. Environment, Biodiversity \& soil security. 1:101-107.

Jaime, M.D.L.A., Hsiang, T., M.R. McDonald, 2008. Effects of Glomus intraradices and onion cultivar on Allium white rot development in organic soils in Ontario. Canadian Journal of Plant Pathology. 30:543-553.

Kloepper, J. W. 1978. Planta growth promoting rhizobacterias on radishes. 2:879-882.

Kumbhar, V.R., Mene, S. R., Birajdar, G. M., Bansode, S. a., Swami, C. S., Bhale, U. N. 2018. Physicochemical characterization and population dynamics of mycoflora in infected rhizosphere soil od onion white rot cuused by Sclerotium cepivorum. Internationa Journal of current Microbioogy and applied Sciences. 7(8):3771-3780.

Lavenus, J., Goh, T., Roberts, I., Guyomarc'h, S., Lucas, M., De Smet, I., Fukaki, H., Beeckman, T., Bennett, M., Laplaze, L. 2013. Lateral root development in Arabidopsis: fifty shades of auxin. Trends Plant Science. 18:450458.

Luna, M. L., Martínez, P. R., Hernández, I. M., Arvizu, M. S. M., Pacheco, A. J. R. 2013. Caracterización de rizobacterias aisladas de tomate y su efecto en el crecimiento de tomate y pimiento. Revista Fitotecnia Mexicana. 36(1):63-69.

Mahdizadhnaraghi, R., Heydari, A., Reza, Z. H., Rezaee, S., Nikan, Jafar. 2015. Biological control of garlic (Allium) White rot disease using antagonistic fungi-based bioformulations. Journal of plant protection research. 55(2):137141.

OCEGUEDA-REYES, Martha Delia, CASAS-SOLÍS, Josefina, GONZÁLEZ-EGUIARTE, Diego R. and VIRGEN-CALLEROS, Gil. Rhizobacteria antagonistic to the fungus Sclerotium cepivorum (Berk.t) in onion plants (Allium cepa L.). Journal of Environmental Sciences and Natural Resources. 2019 
Mejia-Bautista, M. A., Reyes-Ramírez, A., Cristóbal-Alejo, J., Tun-Suárez, M. BorgesGómez, L. del C. 2016. Bacillus spp. en el control de marchitez causada por Fusarium spp. en Capsicum chinense. Revista Mexicana de Fitopatología.

doi:10.18781/R.MEX.FIT.1603-1.

Montor-Antonio, J. J., Olvera-Carranza, C., Reyes-Duarte, D., Sachman-Ruíz, B., RamírezCoutiño, L., Del Moral, S. 2014. Caracterización bioquímica de AmiJ33, una amilasa de Bacillus amyloliquefaciens aislada de suelos cultivados con caña de azúcar en el región del Papaloapan. Nova Scientia. 12 (2):39-59.

Moreno, R. A., García, M. V., Reyes, C. J. L. Vázquez, A. J., Cano, R. P. 2018. Rizobacterias promotoras de crecimiento vegetal: una alternativa de biofertilizante para la agricultura sustentable. Revista Colombiana de Biotecnología. 20:1. 68-83.

Oslizlo, A., Stefanic, P., Vatovec, S., Beigot, G. S., Rupnik, M., Mandic-Mulec, I. 2015. Exploring ComQXPA quorum-sensing diversity and biocontrol potential of Bacillus spp. isolates from tomato rhizoplane. Microbial Biotechnology. 8(3):527-540.

Ortega-Aguilar, B. L., Alarcón, A., FerraraCerrato, R. 2011. Effect of potassium bicarbonate on fungal growth and sclerotia of Sclerotium cepivorum and its interaction with Trichoderma. Revista Mexicana de Micología. 33:53-61.

Paredes-Escalante, J. E., Carrillo-Fasio, J. A., García-Estrada, R. S., Allende-Molar, R., Sañudo-Barajas, J. A., Valdez-Torres, J. B. 2009. Microorganismos antagonistas para el control del complejo de hongos causantes de la rabia del garbanzo (Cicerarietinum L.) en el Estado de Sinaloa, México. Revista Mexicana de Fitopatología. 27:27-35.

Reveles-Hernández, M., Velázquez-Valle, R., Reveles-Torres, L. R., Cid-Ríos, J. A. 2014. Guía para la producción de cebolla en Zacatecas. Folleto Técnico No. 62. Calera, Zac., México. 40p.
Reyes, R. A., Ruiz, S. E., Yam, Ch. C., Dzul, Ch. M. 2011. Selección de Bacillus spp. con antagónica in vitro contra Macrophomina phaseoina (Tassi) Goid. en diferentes medios cultivos. Fitosanidad 15(2): 117-121.

Rios-Velasco, C., Caro-Cisneros, J. N., Berlanga-Reyes, D. I., Ruíz-Cisneros, M. F., Ornelas-Paz, J. J., Salas-Marina. M. A., Villalobos-Pérez, E., Guerrero-Prieto, V. M. 2016. Identification and antagonistic activity in vitro af Bacillus spp. and Trichoderma spp. isolates againts common phytopathogenic fungi. Revista Mexicana de Fitopatología 34 (1):84-99. doi:10.18781/R.MEX.FIT.1507-1.

Rodriguez, G. G. A., Bultrago, J. E., Betancurt, Lara, R. L. 2017. Actividad antagonista de Bacillus frente a Fusarium oxysporum: un aporte a la agricultura sostenible. Nova 3:9-19.

Rojas-Solis, D., Contreras-Pérez, M., Santoyo, G. 2013. Mecanismos de estimulación del crecimiento vegetal en bacterias del género Bacillus. Biológicas. 15(2):36-41.

Rojas-Ruíz, N. E., Vázquez-Cruz, C., SánchezAlonso, P., Sansinenea-Royano, E. 2010. Análisis poblacional de células vegetativas de Bacillus thuringiensis en interacción in vitro con bacterias del suelo. Agrociencias. 44(8):941-953.

Saharan, B.S. y Nehra, V. 2011. Plant Growth Promoting Rhizobacteria: A Critical Review. Life Sciences and Medicine Research.1 Department of Microbiology, Kurukshetra University, Kurukshetra, Haryana, India. 21(1):30.

Salazar-Henao. J. E. Vélez-Bermúdez, I C, Schmidt W. 2016. The regulation and plasticity of root hair patterning and morphogenesis. Develop. 143:1848-1858.

Saleem, M, Arshad, M., Hussain, S., Bhatti, A. S. 2007. Perspective of plant growth promoting rhizobacteria (PGPR) containing ACC desaminase in stress agriculture. Journal of Industrial Microbiology and Biotechnology. 34(10):635-48. 
Sánchez, L. D. B., Pérez, P. J. V., David, H. H. A. 2016. Efecto de la PGPB sobre el crecimiento Pennisetum clandestinum bajo condiciones de estrés salino. Revista colombiana de biotecnología 18(1):65-72. doi:10.15446/rev.colmb.biote.v18n1.50413.

Sarmiento, G. A., Velandía, M. J. 2013. Evaluación de hongos y bacterias aislados de gallinaza en biocontrol de Sclerotium cepivorum Berk. 10(2):37-43.

Secretaría de Agricultura, Ganadería, Desarrollo Rural, Pesca y Alimentación (SAGARPA). 2014. Anuarios estadísticos de la producción agrícola. Servicio de Información Agroalimentaria y Pesquera (SIAP). México, D. F. http://www.siap.sagarpa.gob.mx (consultado el 7 de Agosto de 2019)

Secretaría de Agricultura, Ganadería, Desarrollo Rural, Pesca y Alimentación (SAGARPA). 2019. Anuarios estadísticos de la producción agrícola. Servicio de Información Agroalimentaria y Pesquera (SIAP). México, D. F. http://www.siap.sagarpa.gob.mx (consultado el 9 de septiembre de 2019)

Sarti, C. G., Miyazaki, S. S. 2013. Actividad antifúngica de Extractos crudos de Bacillus subtilis contra fitopatógenos de Soja (Glycine max) y efecto de su inoculación con Bradyrhizobium japonicum. Agrociencia. 47(4):373-383.

Siyoum, Z., Yesuf, M. 2013. Searching and evaluating of cost effective management options of garlic White rot (Sclerotium cepivorum Berk) in Tigray, Northern Ethiopia. Journal Plant Pathology \& Microbiology. 74(7):1-6.

Soto, C. F., Trampon, P. C., Aquevequen, M. P., De Bruijn, J. 2018. Antagonist microorganisms that inhibit the development of post-hasrvest pathogens in lemon (Citrus limon L.). Chilean Journal of Agricultural \& Animal Science. 34(2):173-184.

Tejera-Hernández, B., Rojas-Badía M. M., Heydrich-Pérez, M. 2011. Potencialidades del género Bacillus en la promoción del crecimiento vegetal y el control biológico de hongos fitopatógenos. Revista CENIC Ciencias Biológicas. 42 (3):131-138.
Tariq, J. A., Ahmed, B., Abro, M. A., Ismail, M., Asif, M. U., \& Muhammad, R. 2019. Characterization and bio-antagonistic activity of rhizobacteria against Fusarium oxysporum F. Sp. Cepae. Pakistan Journal of Agricultural Research, 32(2):353-358

Ulacio, D., Jiménez, M. A., Perdomo, W. 2011. Estrategias de manejo integrado de Sclerotium cepivorum Berk., y la pudrición blanca del ajo en carache, estado Trujillo, Venezuela. Bioagro. Barquisimeto. Venezuela 23(2):105-11. Disponible en: http://www.scielo.org.ve/scielo.php?pid=S1316 $-33612011000200005 \&$ script=sci_arttext.

Van Dyk, J.S. \& Pletschke, B. 2011. Review on the use of enzymes for the detection of organochlorine, organophosphate and carbamate pesticides in the environment. Chemosphere. 82. 291-307.

Vega-Celedón, P., Canchignia, M. H., González, M., Seeger, M. 2016. Biosintesis de ácido indol-3-acético y promoción del crecimiento de plantas por bacterias. Cultivos Topicales. 37: 33-39.

Velázquez-Valle, R., Reveles-Hernández, M. 2016. Efecto de agentes de manejo alternativo sobre el desarrollo de pudrición blanca e ajo. Revista Mexicana de Micología. 44. 41-47.

Vera, R., Moreno, B., Acevedo, R., Trujillo, E. 2005. Caracterización de aislamiento de Trichoderma spp. Por tipo de antagonismo y electroforesis de isoenzimas. Fitopatología. Venezolana. 18:1.2-8.

Villareal-Delgado, M. F., Villa-Rodríguez, E. D., Cira-Chávez, L. A., Estrada-Alvarado, M. I. 2017. El género Bacillus como agente de control biológico y sus implicaciones en la bioseguridad agrícola. Revista Mexicana de Fitopatología. 36(1):95-130.

Yesid, A., Sánchez, L. M. 2012. Determinación de metabolitos secundarios a partir de Bacillus subtilis con efecto biocontrolador sobre Fusarium sp. Nova. 10(18): 135-250. 